\title{
OBSERVATIONS CONCERNING THE THICKNESS OF ROCKS ERODED BETWEEN THE CAMBRIAN AND BOLSOVIAN (= WESTPHALIAN C) IN CENTRAL AND WESTERN BOHEMIA
}

\section{Jiř́i Pešek ${ }^{1} \&$ Karel Martínek ${ }^{1}$}

${ }^{1}$ Charles University in Prague, Faculty of Science, Albertov 6, 12843 Praha 2, Czech Republic; email: ir@natur.cuni.cz, karel@natur.cuni.cz

\begin{abstract}
Carboniferous outliers are found west of the late Carboniferous West Bohemian basins and also south of the West and Central Bohemian basins. The West Bohemian group is Asturian (= Westphalian D) or younger and is notably coal-bearing, the other group of outliers consists mostly of coal-bearing upper Carboniferous volcaniclastic rocks of Bolsovian (= Westphalian C) and/or Asturian age. They form a discontinuous belt extending through the area between and around the towns of Merklin and Beroun. These rocks are underlain chiefly by rocks of ages varying from the Neoproterozoic or Cambrian up to the Ordovician. If the nappe structure of the Barrandian Lower Paleozoic proposed by Melichar and Hladil (e.g. 1999) is not widely present, then it can be assumed that as much as $1850 \mathrm{~m}$ of Lower Paleozoic sediments and volcanics could have been eroded prior to the onset of sedimentation of the Bolsovian rocks. In the upper Carboniferous outliers near Mirošov, Skořice and Kamenný Ujezd, where sedimentation began as late as in the Asturian, the thickness of eroded deposits might have been even greater, reaching as much as $3150 \mathrm{~m}$.
\end{abstract}

Keywords: Carboniferous, outliers, Cambrian, Ordovician, Central and Western Bohemian basins, pre-Carboniferous erosion, coal-bearing relics

\section{INTRODUCTION}

There are a number of questions about the geological evolution of the Bohemian Massif (Figure 1) which remain unanswered either because of a lack of consens ususually or because there is not enough data. For example, is the Barrandian Neoproterozoic an upper part of the Moldanubicum or did separate microplates exist originally? At what depth were the Variscan granitoid intrusions (e.g. Central Bohemian Pluton, Čistá-Jesenice and Štěnovice massifs) emplaced and how fast were they exhumed? Some granitoid bodies form the footwall of the oldest unit of the Central and/or West Bohemian Carboniferous (Radnice Member - Bolsovian did the Central Bohemian and/or West Bohemian basins receive eroded sediments from these granitoid bodies? The most westerly occurrences of the Lower Paleozoic deposits of the Barrandian Unit lie on the SE outskirts of the city of Plzen and in the environs of the town of Mirošov: How far to the west did they originally extend? Veleman and Cháb (1974) described contact metamorphosed para-conglomerates, shales with pebbles and banded shales near the village of
Hluboká, ca $3 \mathrm{~km}$ W of Žihle: Are these Barrandian and/or Saxothuringian Cambrian or Ordovician? Was only the Barrandian Lower Paleozoic intensely folded (cf. Chlupáč et al. 2002) or is the Ordovician-Devonian complex of the Barrandian synclinorium a nappe structure as inferred by Melichar and Hladil (e.g. 1999)?

The answers to these questions depend on the rate and depth the sediments and metamorphic rocks and the plutonic and hypabyssal dykes and intrusive bodies and their cover were eroded. It is not clear how thousands of cubic kilometers of rock were removed prior to deposition of the late Carboniferous (= Pennsylvanian) sediments as there are no known deposits of an appropriate age to record this removal and transport of sediment.

The Central and West Bohemian basins were supplied with weathered material from both the crystalline complex and the Barrandian Lower Paleozoic. Evidence of this is provided by the relatively large blocks of upper Cambrian acid volcanites found in mines in the Kladno region (Opluštil 2000) and the Lower Paleozoic rocks that form a 


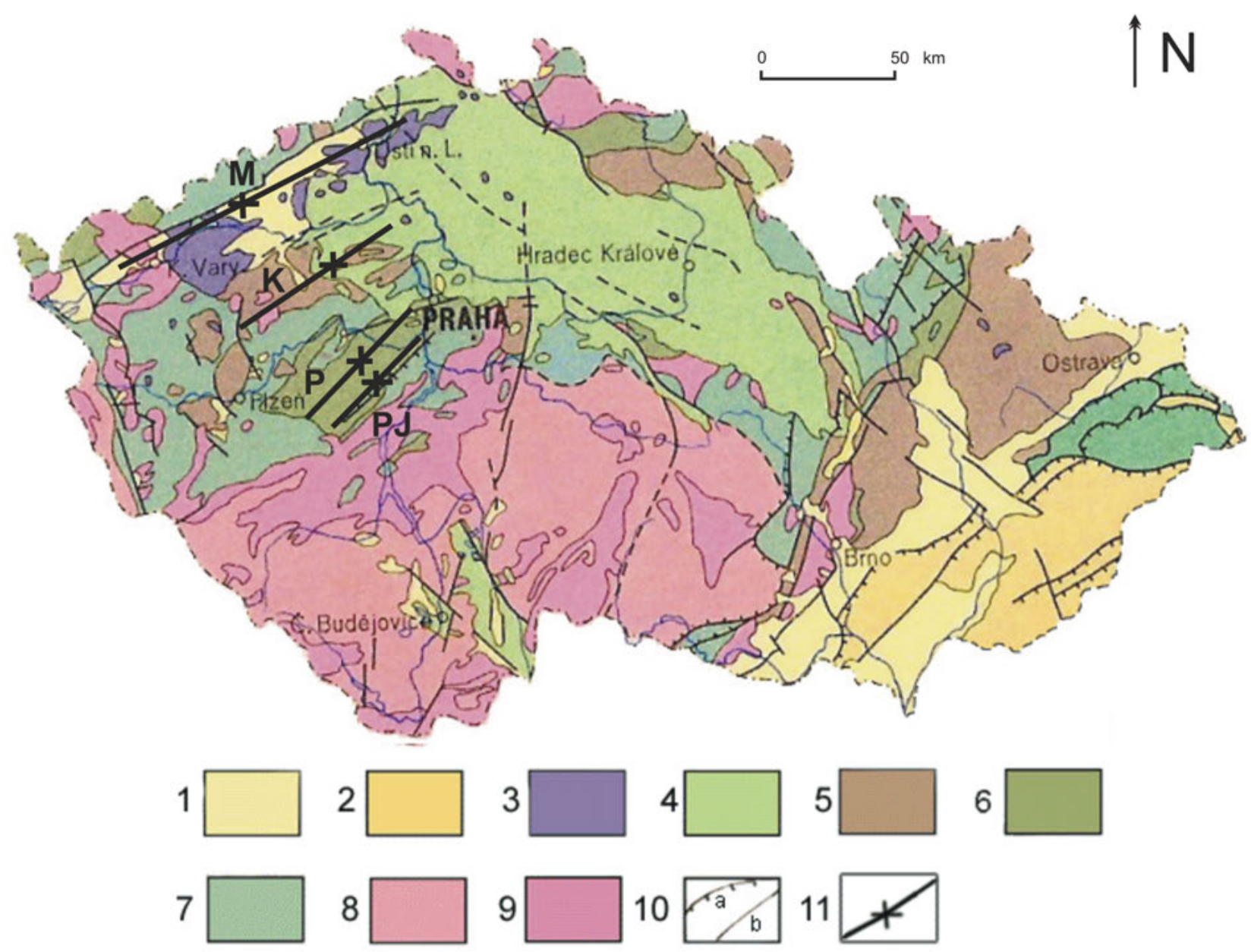

Figure 1. Simplified geological map of the Czech Republic. Modified from Chlupáč et al (2002) and GEOČR500 (2010). 1 Neogene, 2 - Paleogene, 3 - neovolcanites, 4 -Upper Cretaceous, 5 - Upper Paleozoic, 6 - Lower Paleozoic, 7 - Neoproterozoic of the Teplá-Barrandian unit, 8-Moldanubian crystalline complex, 9 - granitoid massifs, 10 - faults and thrust faults, 11- inferred axes of sedimentary basins. Abbreviations used to identify individual basins: PJ - Př́bram-Jince (Cambrian), $P$ - Prague (Ordovician - Middle Devonian), K - Kladno-Rakovník (upper Carboniferous) M - Krušné hory piedmont (Miocene).

significant proportion of the pebbles in conglomerates intersected by borehole HV-21 drilled in the Bolsovian outlier near Holoubkov. Kraft (1962) found that $47 \%$ of these pebbles were derived from the local source rocks. Gregorová (1961) described pebbles of quartz conglomerate and quartzite, possibly of Ordovician age, in the kaolin overburden near Kaznějov in the Plzeň region. Large pebbles of quartzite, volcanics and other rocks are also known from a road cut near the village of Lísek. An occurrence of breccia at the village of Železná near Beroun is more problematic. It contains fragments of Devonian limestone and Kodym (1933) placed this breccia in the upper
Carboniferous. In this context, recent finds of limestone containing Devonian fauna in the environs of Jesenice NE of Žihle are very surprising (K. Žák, R. Lojka, oral communication). It is evident that at least some of the granitoid massifs, shown by Kukal (1984) to be the obvious major source of material for the upper Carboniferous arkoses, must already have been exposed to erosion by the beginning of deposition of the Radnice Member (Bolsovian). Evidence for this conclusion is that the Čistá-Jesenice Massif extends towards the NE in the immediate footwall of the Radnice Member in the Rakovník region, and there is also a significant increase in the sand content along 
the eastern edge of the Plzen Basin (PB) and as well as along the southern boundary of the Kladno-Rakovník (KRB) Basin (cf. Appendix VIII in Pešek 1994).

Based on this evidence, it is supposed that the depth of erosion in the Bohemian Massif must have been significant. There were at least two periods of intense erosion following the major movements of the Cadomian and Variscan orogenesis. Due to this tectonic movements the depocenter shifted from the Přibram-Jince Basin in the Cambrian northwestward as far as the Krušné hory Piedmont basins into the Miocene (Havlíček 1980, Fig. 1).

Spengler (1939) proposed that almost $10 \mathrm{~km}$ had been removed from the eastern part of the Krušné hory Mts. in the early Carboniferous (= Mississippian). Later Sattran (1957) estimated that at least $5 \mathrm{~km}$ had been eroded from the same region. This stands in contrast to the total thickness of $1500 \mathrm{~m}$ of rocks that have been eroded during the period since the Westphalian until the Recent. Bearing in mind that only very approximate estimates can be made, by using the rocks immediately underlying the Central and West Bohemian basins and the Carboniferous outliers in their neighborhood, it is possible to calculate the thickness of rocks eroded prior to the sedimentation of the Radnice Member (Bolsovian) and/or Nýřany Member (Asturian) for which there are reliable palaeontological dates. While the basement of the West and Central Bohemian basins is formed by volcanosedimentary rocks of the Barrandian Neoproterozoic or Cadomian or Variscan granitoids, with the exception of SE edge of the Mšeno-Roudnice Basin, in the footwall of a few Carboniferous outliers and in their neighborhood, Lower Paleozoic deposits, mainly of Ordovician age, are also preserved.

The Upper Paleozoic fill of the Central and West Bohemian basins extended beyond these basin. This is evidenced by the Carboniferous outliers west of the Manětín Basin (MB), west and south of the Plzen Basin (PB) and south of the KladnoRakovník Basin (KRB) (Figure 2). These outliers are arranged in two discontinuous belts with different orientations. Isolated islands of Carboniferous rocks west of the $\mathrm{PB}$ and $\mathrm{MB}$ form a belt running roughly NNW-SSE. Vejnar and Zoubek (1962) called this belt the "Řešín Depression". In contrast, Carboniferous outliers south of $\mathrm{PB}$, the
Radnice Basin (RB) and the KRB are elongated in a NE-SW direction. The large majority of the discontinuous outliers forming the belt that extends from Merklín, SW of the city of Plzeň, as far as the NE environs of Beroun, are coal bearing. In contrast, the upper Carboniferous outliers of the so-called Řešín depression do not contain coal deposits, with the exception of small outliers at the villages of Skapce, Těchlovice and Vranov near Stříbro (Kalibová-Kaiserová 1979, 1982, Šetlík in Pertold et al. 1966). Gold has been mined from the upper Carboniferous at the village of Krrivce $\mathrm{N}$ of the town of Konstantinovy Lázně as early as in 1342 (Klomínský et al. 1979).

The occurrence of Carboniferous outliers raises the following questions:

1) What was the initial extent of sediments of Central and West Bohemian basins?

2) How did the outliers that are found in the area bordering these basins originate and why were they preserved in their present positions?

3) What is the approximate thickness of chiefly Lower Paleozoic rocks that was eroded from these basins?

\section{The original extent of Carboniferous units west of the Manětín Basin, west and south of the Plzeň Basin and south of the Radnice and Kladno-Rakovník basins}

The composition and age of the upper Carboniferous outliers in the neighborhood of the abovementioned basins has recently been summarized in a study by Pešek (2003). The best predictions about the extent of individual formations in the West and Central Bohemian basins are graphically illustrated in studies by Holub et al. (1975), Havlena and Pešek (1980) and Pešek et al. (1998). As regards the oldest, most productive Radnice Member (Table 1), it is evident that sediments of this unit occur chiefly in parts of the $\mathrm{PB}, \mathrm{RB}$ and $\mathrm{KRB}$ and south of these basins. In West and Central Bohemia, these deposits mainly fill depressions, the roughly NE-SW trend governed by the regional structure. In addition, there are pre-sedimentary (?) and obviously syn-sedimentary depressions of NNE-SSW trend (Central Depression of the Plzen Basin) and depressions elongated in a NNW-SSE direction (Rakovník part of KRB and depression 
between the Třtěno and Peruc villages in the Kladno part of this basin). With the exception of the Mirošov-Skořice and perhaps the Kamenný Újezd ${ }^{1)}$ Carboniferous outliers where sedimentation began as late as the Asturian (boreholes and underground workings, chiefly in the Mirošov region, prove their age), there are also upper Carboniferous outliers occurring between Merklín and the village of Malé Přilepy NE of Beroun. It is believed that the Radnice Member did not extend further $\mathrm{W}$ of the $\mathrm{PB}$ and $\mathrm{MB}$ because there the outliers consisting exclusively of Asturian or younger deposits.

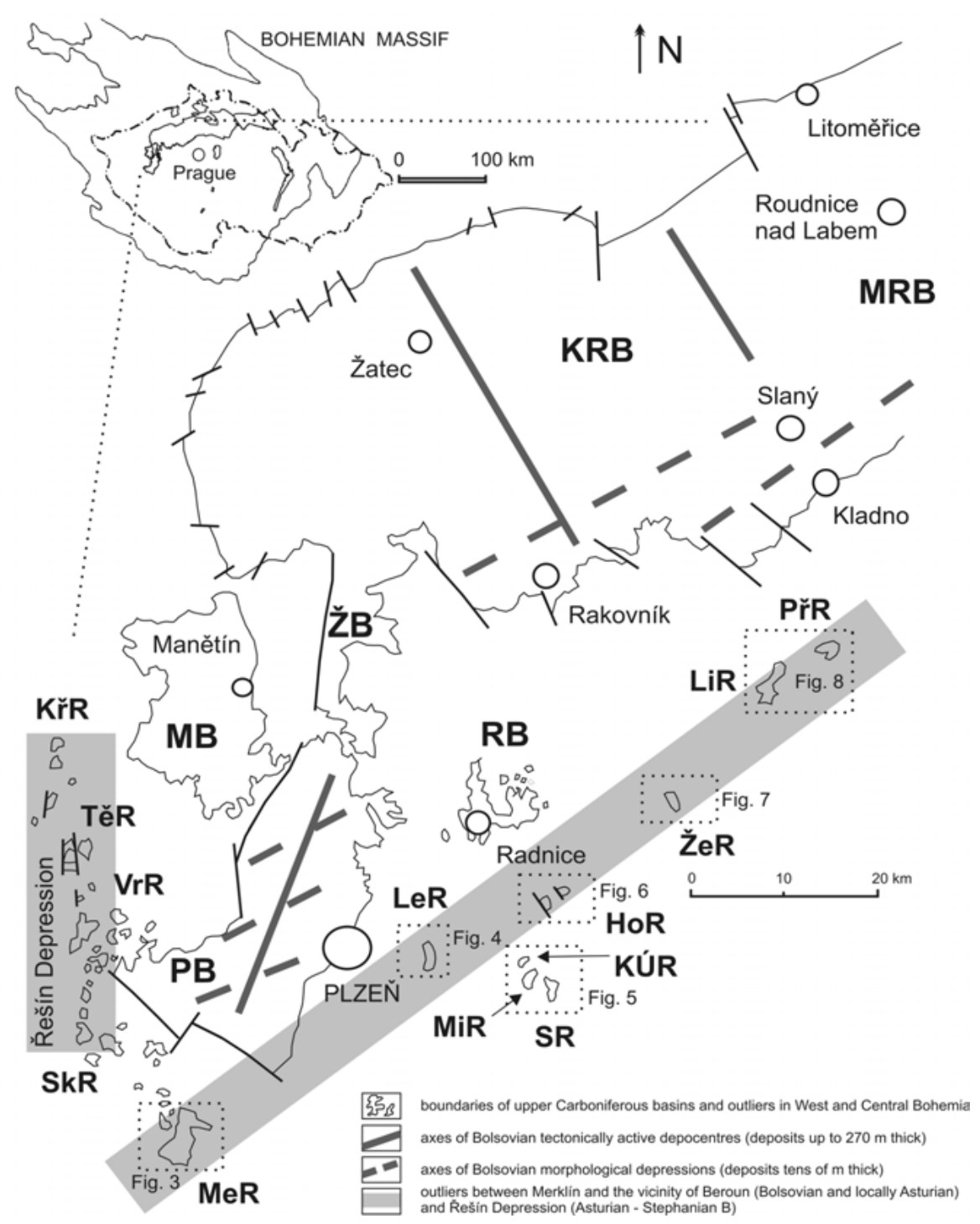

Figure 2. Schematic depiction of the extent of Central and West Bohemian late Carboniferous basins and outliers in their neighborhood. Modified from Pešek (2003) and Holub et al. (1979). Basins and outliers in West and Central Bohemia - basins: PB Plzeň, MB - Manětín, ŽB - Žihle, KRB - Kladno-Rakovník, MRB - Mšeno-Roudnice; outliers: KřrR - Kř̀ivce, TěR - Těchlovice, SkR - Skapce, VrR - Vranov, MeR - Merklín, LeR - Letkov, MiR - Mirošov, SR - Skořice, KÚR - Kamenný Újezd, HoR - Holoubkov, ŽeR - Žebrák, LíR - Lísek and Hýskov, PřR - Malé Přílepy.

\footnotetext{
1) Only a short note exists in the study of the Carboniferous outlier at Kamený Újezd by Kraft and Kraft (2006), including a remark about the coal-bearing part of the sequence.
}

Sediments belonging to the Radnice Member do not occur in the MB and only one locality in the Žihle Ba$\sin (\check{Z} B)$. Bolsovian sediments fill the majority of upper Carboniferous outliers $\mathrm{S}$ of the Central and West Bohemian basins. However, it is not clear whether these outliers were an integral part of a larger, more continuous area covered by the Radnice Member (Pešek et al. 1998, Appendix 34), or whether deposition took place discontinuously along the NNE - SSW trending belt because, in none of the basins mentioned above do the sediments of the Radnice Member have the same composition as those deposited along their edges. Similarly, the sedimentary successions in all the outliers, except for the Carboniferous outlier near Lísek, indicate that these deposits must have covered a larger area than they do at present. At Lísek, coarse conglomerates with well rounded cobbles; averaging $20-25 \mathrm{~cm}$ in diameter; of quartz, quartzite, igneous and other rocks are found often interbedded with subhorizontal beds of coal close to the basin margins.

The Radnice Member flora has not been found in any of the upper Carboniferous 
Table 1. Simplified stratigraphy of the late Carboniferous basins of Central and Western Bohemia. Based on Heckel (2002) and authors.

\begin{tabular}{|c|c|c|c|c|c|c|c|}
\hline system & subs. & series & stage & $\begin{array}{c}\text { W. European } \\
\text { stages }\end{array}$ & $\begin{array}{c}\text { W. European } \\
\text { substages } \\
\end{array}$ & $\begin{array}{l}\text { local stages } \\
\text { (Formations) }\end{array}$ & $\begin{array}{c}\text { local substages } \\
\text { (Members) }\end{array}$ \\
\hline \multirow{24}{*}{ 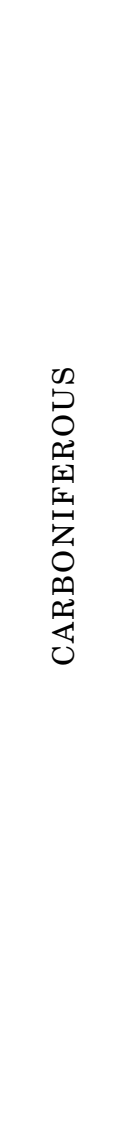 } & \multirow{17}{*}{ 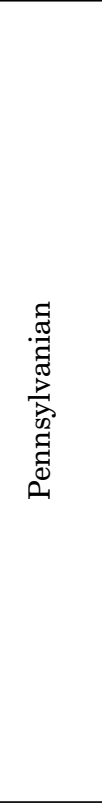 } & \multirow{7}{*}{ Upper } & \multirow{5}{*}{ Gzhelian } & \multirow{8}{*}{ Stephanian } & Autunian & \multirow{2}{*}{ Líně } & \\
\hline & & & & & $\mathrm{C}$ & & \\
\hline & & & & & \multirow{4}{*}{ B } & \multirow{4}{*}{ Slaný } & Kounov \\
\hline & & & & & & & Ledce \\
\hline & & & & & & & Malesice \\
\hline & & & \multirow{2}{*}{ Kasimovan } & & & & Jelenice \\
\hline & & & & & Barruelian & Týnec & \\
\hline & & \multirow{5}{*}{ Middle } & \multirow{5}{*}{ Moscovian } & & Cantabrian & \multirow{3}{*}{ Kladno } & \multirow{2}{*}{ Nýřany } \\
\hline & & & & \multirow{4}{*}{ Westphalian } & Asturian & & \\
\hline & & & & & Bolsovian & & Radnice \\
\hline & & & & & Duckmantian & & \\
\hline & & & & & Langsetian & & \\
\hline & & & & & Yeadonian & & \\
\hline & & & & & Marsdenian & & \\
\hline & & Lower & Bashkirian & & Kinderscoutian & & \\
\hline & & & & Namurian & Alportian & & \\
\hline & & & & & Chokierian & & \\
\hline & & Upper & Serpuchovian & & Arnsbergian & & \\
\hline & $\approx$ & & & & Pendlian & & \\
\hline & 愛 & & & & Warnantian & & \\
\hline & $\begin{array}{l}\overrightarrow{7} \\
.0 \\
.02\end{array}$ & Middle & Visean & Visean & Livian & & \\
\hline & 䨔 & & & & Molinisian & & \\
\hline & & Lower & Tournaisian & Tournaisian & Ivorian & & \\
\hline & & & & & Hastarian & & \\
\hline
\end{tabular}

outliers $\mathrm{W}$ of the PB nor in the MB. In those instances in which the age of the sedimentary fill is known (Vranov E and Těchlovice $\mathrm{N}$ of Stříbro and at Skapce S of Stříbro) the floras are of Asturian age. Based on plant remains the upper Carboniferous outliers near Mirošov and Skořice are of Asturian age. The age of the outlier near Kamenný Újezd deposit is not certain, but also Asturian age is assumed. No Bolsovian sediments are known in the footwall of the Mirošov-Skořice outlier (Čepek 1951). Bolsovian strata are also absent in the Kamenný Újezd outliers.These are not part of the belt of outliers extending between Merklín and Malé Přílepy near Beroun, but lie ca $10 \mathrm{~km}$ SE of it. Based on this evidence, deposition of Radnice Member or equivalent sediments did not occur near Mirošov, Skořice and Kamenný Újezd, SE of Rokycany. Thus sedimentation around these outli- ers probably extended only slightly beyond their present SE boundary.

The Týnec Formation (Barruelian) resting on Neoproterozoic or Lower Paleozoic basement has only been documented in the MB and KRB. The possibility that this relationship existed elsewhere cannot be excluded with certainty. This uncertainty is due to the lack of fossils in The Týnec Formation and the character of the sediment of the Nýrany Member where it was deposited along the original boundaries of Central and West Bohemian basins are indistiguishable from sediments of the Týnec Formation. This facies of the Nýrany Member were described and refered to by Havlena and Pešek (1980) as the Kačice facies. The problem of assigning the uppermost coarse detrital units of Carboniferous Týnec Formation near Křivce, S of Konstantinovy Lázně, to one or the 
other two members is pointed out by Klomínský et al. (1983). Another example is in boreholes V4b/62 and $6 \mathrm{~b} / 62$ at Těchlovice, south of Střibro (Pertold et al. 1966) in which thin coal beds were incountered. This coal south of the village mined for a short period of time (Pešek 1960). Therefore, the discovery of a Stephanian flora by Šetlík (Šetlík in Pertold et al. 1966) in borehole $12 \mathrm{~b} / 63$, at the village of Cebiv near Stříbro, is crucial since the sediments in the core resemble those of the Malesice Member at the base of the Slaný Formation in the $\mathrm{MB}$ and along the NW and N boundary of the KRB. About $50 \mathrm{~m}$ of conglomerate and feldspathic sandstones is present in the footwall of these deposits. These sandstones could be either anomalous facies of the Jelenice Member of the Slaný Formation or typical sediments of the Týnec Formation. Upper Stephanian volcaniclastics of the Líně Formation do not occur in any of Carboniferous outliers W and S of the Central and West Bohemian basins. However, some boreholes, drilled into the basement, contain sediment distinct from the Líně Formation overlaying the Neoproterozoic basement along the NW edge of the KRB (e.g. borehole Vm-3 Velemyšleves $\mathrm{N}$ of Žatec).

\section{Reasons why the Carboniferous outliers bordering the Central and West Bohe- mian basins were formed and preserved at their present locations}

The majority of upper Carboniferous outliers occurring $\mathrm{W}$ of the $\mathrm{MB}$ and $\mathrm{PB}$ unconformably overlie Neoproterozoic deposits. The outliers $\mathrm{S}$ of the $\mathrm{PB}, \mathrm{RB}$ and KRB overlie, unconformably, slightly metamorphosed Neoproterozoic shales and graywackes, and pre-Variscan granitoids of the Stod Massif (at Merklín). Elswhere they unconformably overlie Neoproterozoic shales, graywackes, lydites, spilites and tuffs or Lower Paleozoic rocks (at Letkov, Mirošov-Skořice-Kamenný Újezd and between Lísek and Malé Přílepy) or rest directly on tectonically deformed Lower Paleozoic (outliers at Holoubkov, Žebrák and Malé Př́lepy).

The western part of the upper Carboniferous outlier near Merklín is formed by sediments derived from Neoproterozoic shales and graywackes, while granitoids of the Stod Massif lie $\mathrm{E}$ of the outlier and contributed to the detrital sediments of the eastern part of the Merklín outlier (Figure 3). North of the upper Carboniferous outlier at Letkov (Figure 4), E of the PB, Neoproterozoic shales, graywackes and lydites of the KralupyZbraslav Group occur, while the remaining part of this outlier is bordered by shales and quartzites of the Dobrotivá (Dobrotivian) and quartzites of the Libeň (Berounian) formations (Table 2) (Mašek 1994). To the south, west of Mirošov (Figure 5) Havlíček (1951a, 1951b, 1951c, 1986) and Mašek (1990) identified the Neoproterozoic KralupyZbraslav Group (shales, graywackes and spilite tuffs), and the eastern and north-eastern edge of this outlier contains erroded sediments from the lower Cambrian conglomerates, arkoses, sandstones and graywackes of the Holšiny-Hořice Formation (Table 3). The area in the immediate north-eastern and north-western of this outlier consists of andesites, basalts and pyroclastics of the upper Cambrian Strašice Complex, locally containing intercalations of the Pavlovsko Formation.

According to Čepek (1951), Algonkian (= Neoprotoerozoic) rocks were found in footwall of upper Carboniferous sediments only in the abandoned Antonín mine NW of Mirošov near the NW

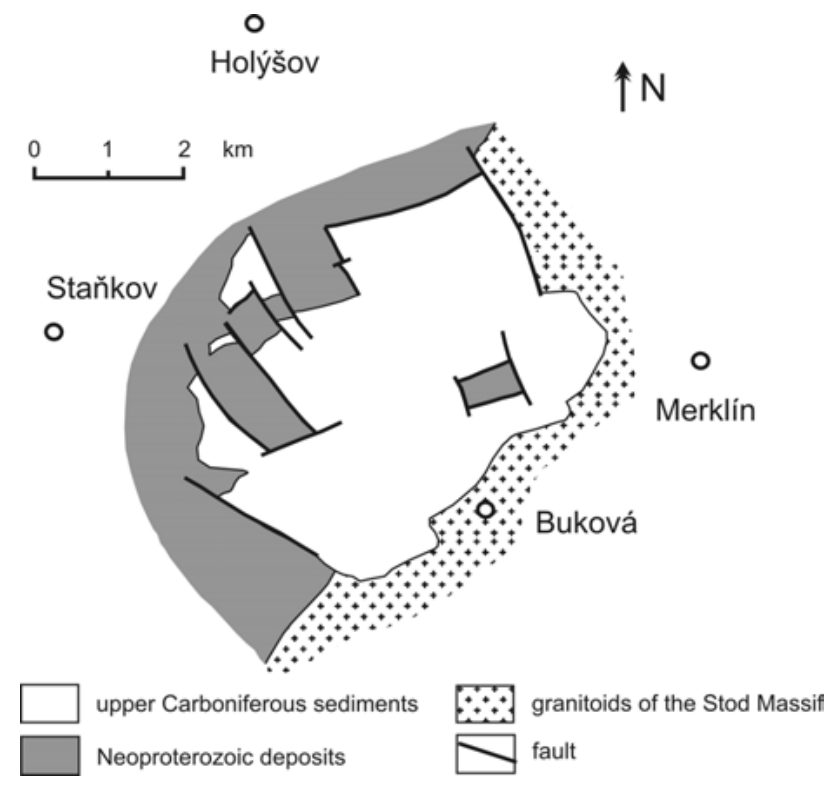

Figure 3. Simplified geological map of the environs of the upper Carboniferous outlier at Merklin. Based on the maps by Vejnar and Pelc (1997), Seifert et al. (1995) and GEOČR50 (2010). The map depicts only Neoproterozoic and Paleozoic units. Upper Carboniferous volcanogenic and sedimentary rocks include Nýrany Member (Cantabrian and Asturian) and Radnice Member (Bolsovian). 


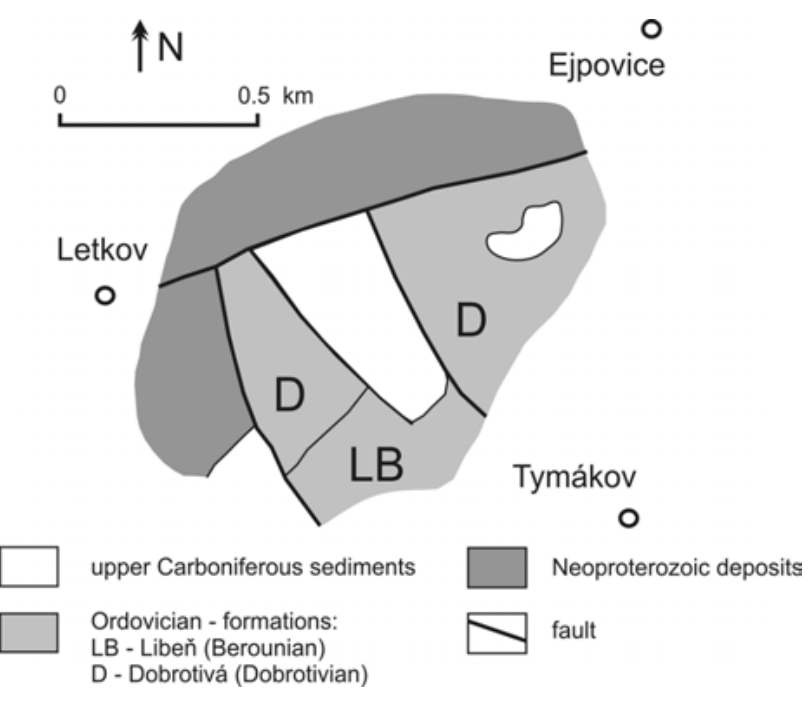

Figure 4. Simplified geological map of the neighborhood of upper Carboniferous outlier at Letkov. Modified from the maps of Mašek and Straka (1994a) and GEOČR50 (2010). Only Neoproterozoic and Paleozoic units are depicted on the map.

edge of this outlier. On the other hand, in the neighborhood of the outlier near Skořice (Figure 5) only detrital deposits of the Holšiny-Hořice Formation are found. Isolated upper Carboniferous outliers located W of the NW edge of the Mirošov outlier and in the environs of Kamenný Újezd are bordered by Neoproterozoic shales and graywackes, then deposits of the Pavlovsko Formation of late Cambrian age, volcaniclastics and sediments of the Olešná Member of the Klabava Formation (Arenigian) and Šárka (Oretanian) and Dobrotivá (Dobrotivian) formations, all of them Ordovician in age. Four small upper Carboniferous outliers lie between Holoubkov and Těškov (Figure 6). Porphyritic diorites of the Krrivoklát-Rokycany Complex crop out north-west and north of Holoubkov. According to Havlíček (1986), in the neighborhood of all these outliers, shales of the Klabava Formation (Arenigian) occur. Klabava Formation like sediments were obtained from borehole HV-21 in the footwall of the Bolsovian SW of Holoubkov (Kraft 1962). The south-western edge of the outlier near Holoubkov is bordered by shales of the Šárka Formation (Oretanian). Shales and quartzites of the Dobrotivá (Dobrotivian) Formation and volcanites of Komárov Complex occur along the north-western edge of the outlier near Těškov. As reported by Havlíček (1986), there are detrital deposits of
Table 2. Simplified stratigraphy of the Barrandian Ordovician. Based on Kraft (pers. comm.).

\begin{tabular}{|c|c|c|c|}
\hline system & stage & regional stage & Formation \\
\hline \multirow{13}{*}{ 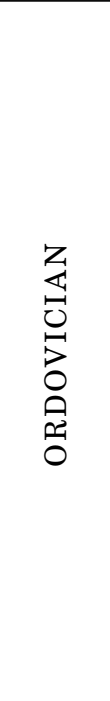 } & Hirnantian & Kosovian & Kosov \\
\hline & Katian & Králodvorian & Králův Dvůr \\
\hline & \multirow{5}{*}{ Sandbian } & \multirow{5}{*}{ Berounian } & Bohdalec \\
\hline & & & Zahořany \\
\hline & & & Vinice \\
\hline & & & Letná \\
\hline & & & Libeň \\
\hline & \multirow[b]{2}{*}{ Darriwilian } & Dobrotivian & Dobrotivá \\
\hline & & Oretanian & Šárka \\
\hline & Dapingian & \multirow{2}{*}{ Arenigian } & \multirow{2}{*}{ Klabava } \\
\hline & Floian & & \\
\hline & \multirow{2}{*}{ Tremadocian } & \multirow{2}{*}{ Tremadocian } & Mílina \\
\hline & & & Třenice \\
\hline
\end{tabular}

the Třenice and Mílina formations (Tremadocian), overlain by shales of the Liben and Vinice formations (Berounian) observed in the cores from boreholes drilled to the basement below the Radnice Member (e.g. borehole Ž-22). Some volcaniclastic rocks of the Zahořany Formation (Berounian) also occur in the neighborhood of this outlier. Based on the map compiled by Havlíček and Štorch (1986), Neoproterozoic shales and graywackes of the Kralupy-Zbraslav Group occur along the boundary of the upper Carboniferous and to the $\mathrm{W}$ and $\mathrm{N}$, perhaps beneath the largest outlier located between Lísek and Hýskov (Figure 8) NW of Beroun. Its eastern edge is bordered by shales and quartzites of the Dobrotivá (Dobrotivian) and Libeň (Berounian) formations, followed by shales of the Letná Formation (Berounian) and volcano-sedimentary rocks of the Komárov Complex. Sediments of the Dobrotivá (Dobrotivian), Libeň, Letná and Vinice (all Berounian) formations and the volcanogenic Komárov Complex occur near the small outlier SW of Železná, N of Beroun (Figure 8). Shales, graywackes and quartzites of the Dobrotivá (Dobrotivian), Libeň, Letná and Vinice (all Berounian) formations are reported by Havlíček and Štorch (1986) near of the upper Carboniferous outlier at Malé Př́lepy, NE of Beroun. Holub and Obrhel (1967) reported Ordovician rocks in 
Table 3. Simplified stratigraphy of the Barrandian Cambrian. Based on Fatka (pers. comm.) and Chlupáč et al. (2002).

\begin{tabular}{|c|c|c|c|c|}
\hline system & series & stage & Příbram-Jince Basin & Křivoklát-Rokycany Basin \\
\hline \multirow{11}{*}{ 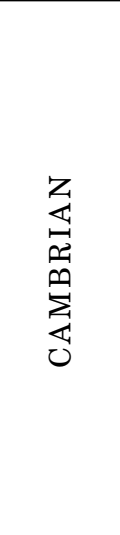 } & \multirow{3}{*}{ Furongian } & Stage 10 & \multirow{3}{*}{ volcanics } & \multirow{5}{*}{ volcanics } \\
\hline & & Stage 9 & & \\
\hline & & Paibian & & \\
\hline & \multirow{4}{*}{ Series 3} & \multirow{2}{*}{ Guzhangian } & Pavlovsko Fm. & \\
\hline & & & Ohrazenice Fm. & \\
\hline & & Drumian & Jince Fm. & Buchava Fm. \\
\hline & & Stage 5 & Chumava-Baština Fm. & \\
\hline & \multirow[t]{2}{*}{ Series 2} & Stage 4 & Klouček-Cenkov Fm. & \\
\hline & & Stage 3 & $\begin{array}{l}\text { Holsiny-Horice Fm. } \\
\text { Sádek Fm. }\end{array}$ & \\
\hline & \multirow[t]{2}{*}{ Terreneuvian } & Stage 2 & Žitec-Hluboš Fm. & \\
\hline & & Fortunian & & \\
\hline
\end{tabular}

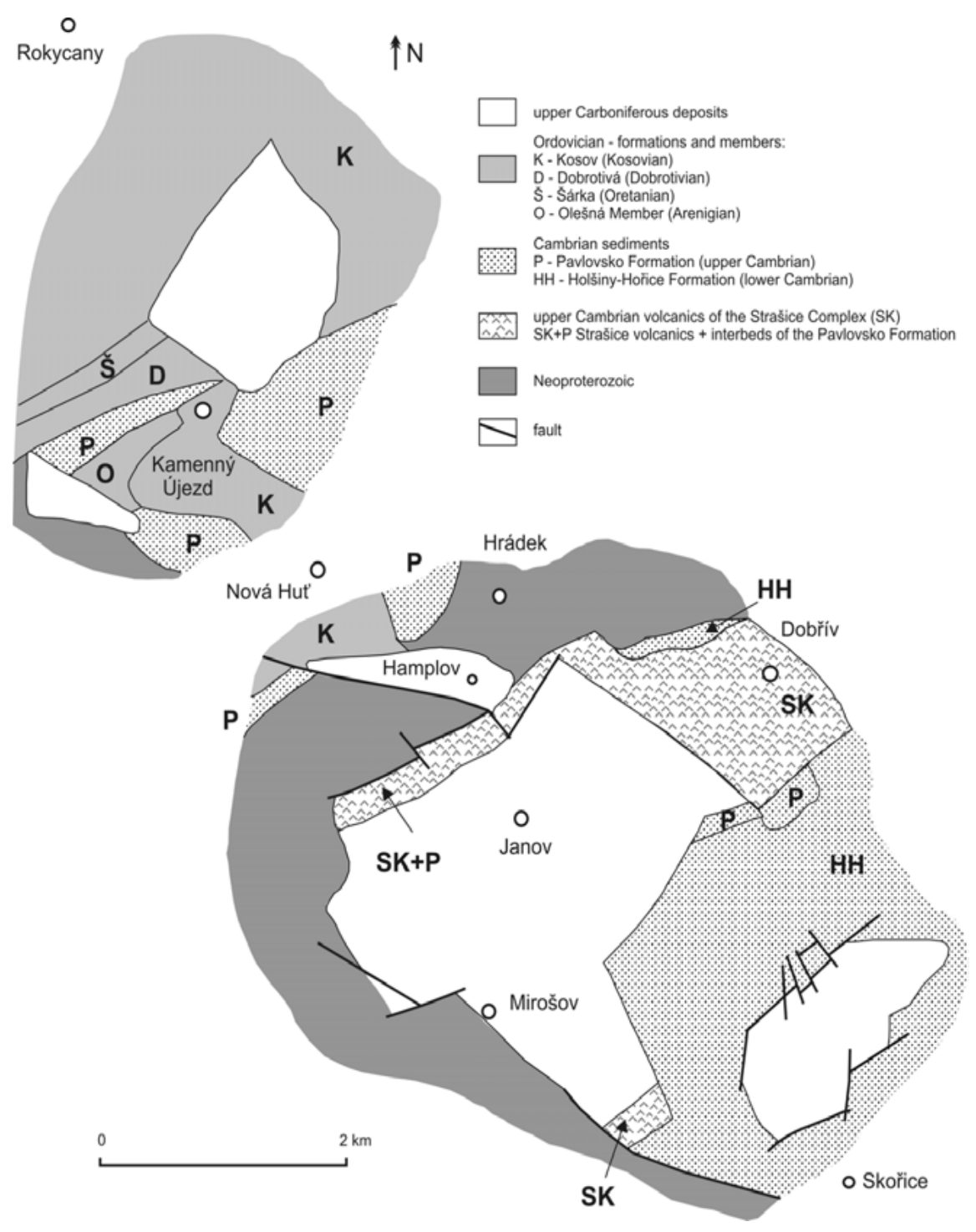

the immediate footwall of the Radnice volcano-sedimentary rocks, but no further details are given. Upper Carboniferous outliers between the villages of Lísek, Hýskov and the villages of Železná and Malé Př́lepy near the city of Beroun lie either on the Prague Fault or in its immediate proximity (cf. Kř́íz 1992) and/or at the south-eastern edge of the $3^{\text {rd }}$ Domain of Proterozoic rocks (sensu Hajná et al. 2010), i.e. on the boundary between the Zbiroh-Šárka belt of Proterozoic age (Röhlich 1965) and the Barrandian Lower Paleozoic area.

Figure 5. Simplified geological map of the neighborhood of the upper Carboniferous outliers at Mirošov, Skořice and Kamenný Ujezd. Modified from the maps compiled by Havliček (1951a, 1951b, 1951c, 1986), Mašek et al. (1990), Mašek and Straka (1994a, 1994b) and GEOČR50 (2010). Only Neoproterozoic and Paleozoic units are depicted on the map. 


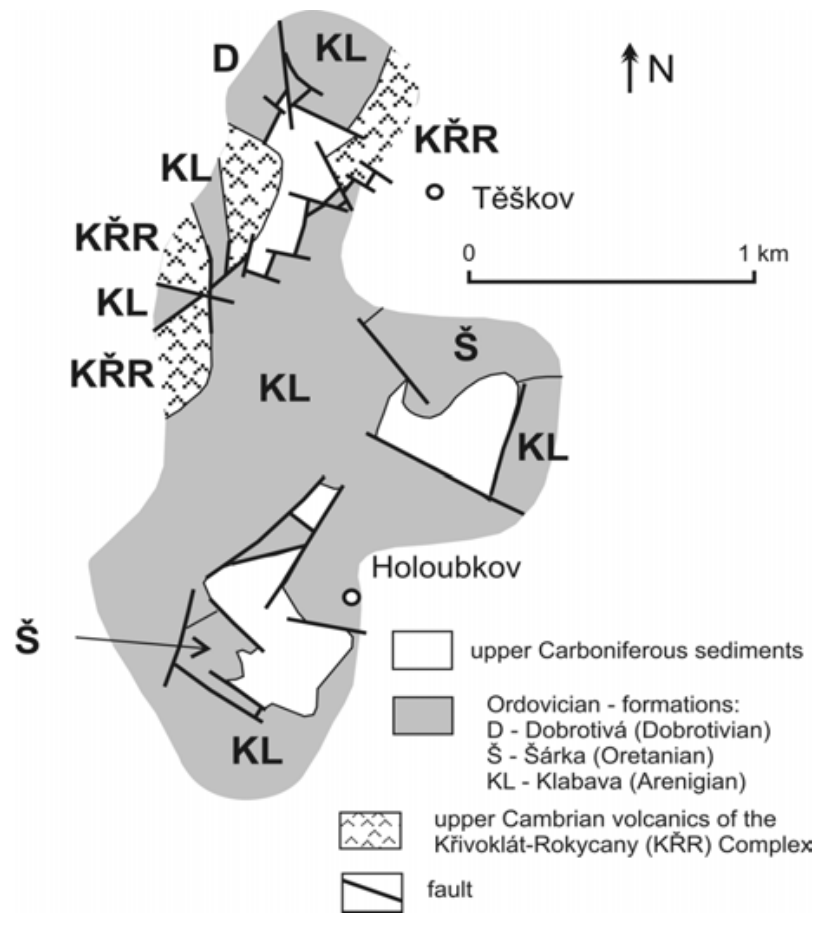

Figure 6. Simplified geological map of the neighborhood of upper Carboniferous outlier at Holoubkov. Modified from the maps of Havliček and Storch (1986) and GEOCR50 (2010). Only Paleozoic units are depicted on the map.

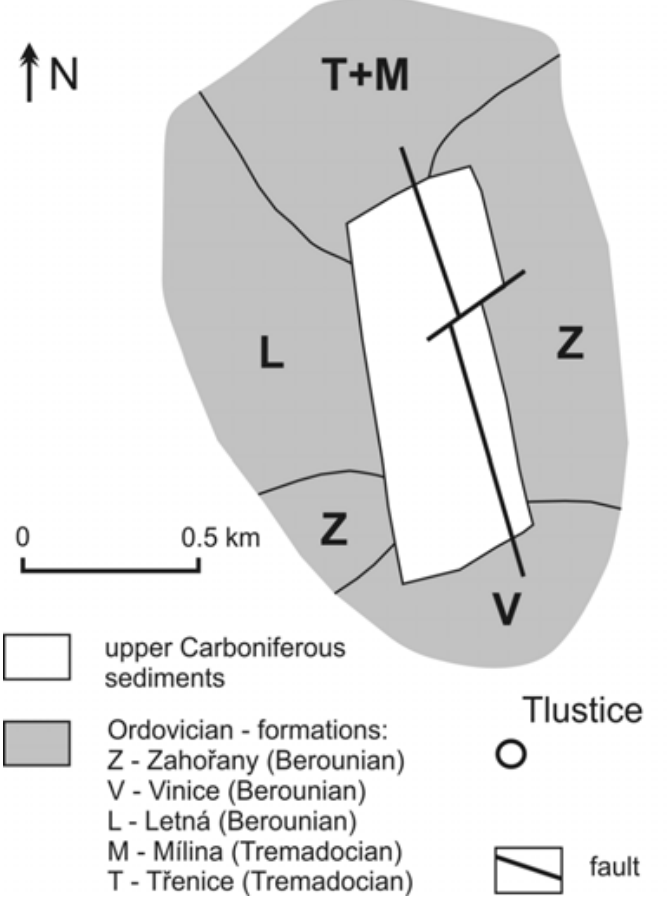

Figure 7. Simplified geological map of the neighborhood of the upper Carboniferous outlier at Zebrák. Modified from the maps of Havliček (1986), Mašek et al. (1983) and GEOČR50 (2010). Only Paleozoic units are depicted on the map.

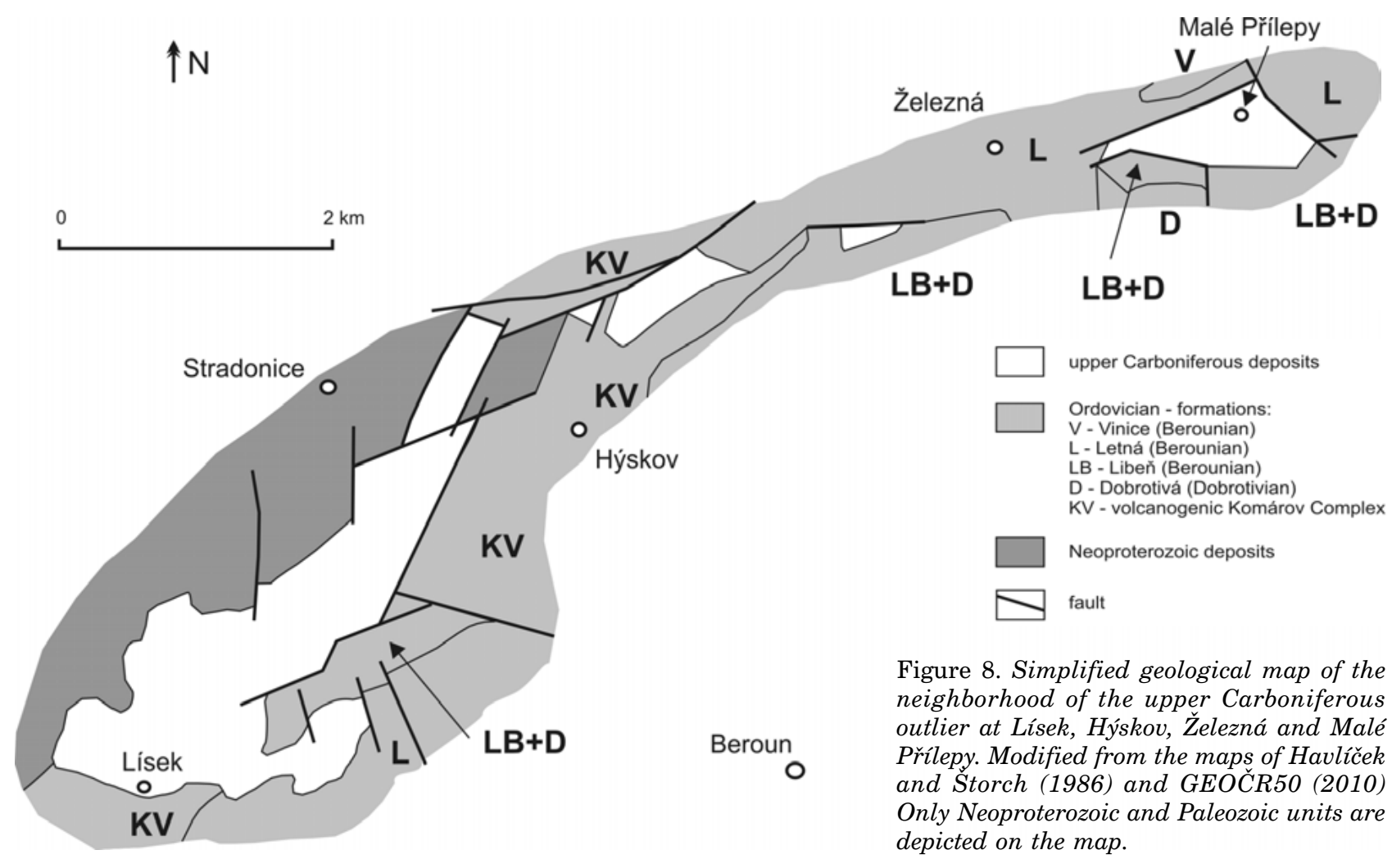




\section{Rough estimates of the thickness of Neoproterozoic and Lower Carbonifer- ous rocks eroded from the footwalls of Carboniferous outliers south of the Central and West Bohemian Late Paleo- zoic basins}

There is a lack of direct evidence that would enable the thickness and volume of Neoproterozoic rocks, eroded prior to the onset of sedimentation of Lower Paleozoic and/or upper Carboniferous deposits, to be calculated. However, the upper Carboniferous outliers located south of Central and West Bohemian basins provide very interesting indirect evidence that there was intense erosion of the Barrandian Lower Paleozoic. However, it is absolutely evident that the surface of Neoproterozoic rocks, differently resistant to erosion and deformed by faulting and folding, was not completely flattened to form a peneplain prior to the onset of sedimentation of the Cambrian PríbramJince Basin and/or before the formation of the Prague Basin. The initial differences in thickness of the Barrandian Lower Paleozoic could have also resulted from different rate of the basement subsidence and its individual tectonically isolated segments both in the Príbram-Jince Basin (Fatka in Geyer et al. 2008) as well as in the Prague Basin. The evidence of segmentation in NE part of the Prague Basin was demonstrated by Kř́ž (1992). Significant differences in thickness of sediments filling both basins are believed to have also resulted from partial or complete erosion of Lower Paleozoic rocks of certain units due to their local deformation by intense folding during the early stages of Variscan orogeny (see the synclinal and anticlinal structure of the Barrandian near Holoubkov described, e.g., by Halíček and Prantl 1951) and their subsequent pre-Bolsovian or pre-Asturian erosion. We here first presume that Cambrian deposits SE of the Prague Basin and S and SE of the Radnice Basin were likely deposited close to the SW and NE edge of the Příbram-Jinec Basin (cf. Havlíček 1971) and that the Ordovician rocks were deposited close to the edges of the Prague Basin (Havlíček 1982). Because of small number of boreholes that were drilled to the basement complex, it is difficult acurrately estimate the thickness of Lower Paleozoic rocks eroded prior to the deposition of Bolsovian and Asturian sedi- ments preserved in the upper Carboniferous outliers south of the Prague and in the Radnice and Kladno-Rakovník basins. Even using the thicknesses of the units reported by Chlupáč et al. (2002), we estimate that a few thousands meters of volcaniclastic and sedimentary rocks to have been eroded prior to the Carboniferous basins formation.

The thickness of Neoproterozoic rocks and the amount of the roof of the granitoid eroded at Merklín is difficult to estimate. If the greater part of the Ordovician (ca $1000 \mathrm{~m})$, Silurian $(350 \mathrm{~m})$ and Lower Devonian volcaniclastics $(200 \mathrm{~m})$ were eroded at Letkov, then at least $1550 \mathrm{~m}$ have been eroded from this area. Prior to deposition of the Asturian sediments, roughly $1300 \mathrm{~m}$ of Cambrian, up to $1300 \mathrm{~m}$ of Ordovician and as much as $550 \mathrm{~m}$ of Silurian and Lower Devonian rocks might have been eroded from the area around Mirošov, Skořice and Kamenný Újezd. At Holoubkov and all the other Carboniferous outliers in which sedimentation had started by the Bolsovian the erosion and removal of all Ordovician, Silurian and Lower Devonian volcano-sedimentary rocks amounting to $1850 \mathrm{~m}$ must have been removed by erosion. A similar thickness of Ordovician to Lower Devonian rocks could have also been eroded from the footwall of the Carboniferous outlier between Tlustice and Žebrák. Similarly, approximately $700 \mathrm{~m}$ of Ordovician volcano-sedimentary rocks and $550 \mathrm{~m}$ of Silurian and Lower Devonian rocks could have been eroded prior to the deposition of the Bolsovian starta that has become the Carboniferous outlier between Lísek and Hýskov, near Železná and at Malé Př́ílepy near Beroun. These estimates are not in disagreement with the thickness of Cambrian rocks that Fatka and Mergl (2009) estimated as being present in the PříbramJince Basin. However, based on an investigation of the maturity of organic matter and the analysis of fission tracks in apatite from the Barrandian Lower Paleozoic, Franců et al. (1998), Glasmacher et al. (2002), Šafanda et al. (2003), and Filip and Suchý (2004) concluded that the Middle Devonian rocks were covered by no less than $2-3 \mathrm{~km}$ of preupper Carboniferous rocks. If this was the case, then a significantly greater thickness of pre-Bolsovian and/or pre-Asturian deposits must have been eroded prior to deposition of the Radnice and Nýřany members. 


\section{DISCUSSION AND CONCLUSIONS}

Despite of many basin analyses, sedimentological, mineralogical and geochemical studies, some aspects of the palaeogeographic setting of Late Palaeozoic continetal basins of Central and Western Europe remain open to debate. Skoček in Holub et al. (1991) and Becq-Giraudon et al. (1996) argue for mountainous terrain with high-altitude periglacial conditions in Bohemian Massif and Massif Central during the Westphalian and Autunian. According to these authors, poorly weathered feldspathic clasts and presennce of illite-chloriteirregular interlayered clays are indicative of cold climatic conditions. The flora and entomofauna and the presence of seasonal lamination in lacustrine deposits (Martínek et al. 2006) indicating a seasonal climate, point in an equatorial of a mountain range higher than $4500 \mathrm{~m}$ a.s.l.

Alternativly Holub and Pešek in Holub et al. (1991) interpret the Permo-Carboniferous palaeotopography of the Bohemian Massif as low mountains. Their assumptions are based on the small thickness of basal clastics, which are localised at the basin margins, low pre-depositional relief (maximum elevation difference is $200 \mathrm{~m}$ ) of oldest formations, and relatively low maximum elevation difference of the basement - $1800 \mathrm{~m}$ (present-day, including post-depositional deformation). Based on the study of numerous basins in Czech, Germany, France and Morroco, Roscher and Schneider (2006) argue that a Trans-Pangean Mountain Belt was eroded and no longer exists but never exceeded an average elevation of $2000 \mathrm{~m}$ since at least Stephanian B. The lack of an orographic barrier led to a strong seasonality which is explained by moving Inter-Tropical Zone of Convergence (ITC) over larger distances than today. ITC was moving to the north and south during dry winter and summer seasons. Data from Erzgebirge Basin point to very fast exhumation of Variscan crystalline complexes and to very rapid erosion prior the end of Mississippian. Its palaeotopography is interpreted as low mountains with maximum elevation about $1000 \mathrm{~m}$ a.s.l. (Schneider et al. 2005).

Upper Carboniferous rocks are preserved in rather small outliers $\mathrm{W}$ of the West Bohemian late Carboniferous basins and S of the West and Central Bohemian basins. While in the first group of outliers, Asturian in age (= Westphalian D) or younger, coal is rare, the second group of outliers consists mostly of coal-bearing Bolsovian (= Westphalian C) or the productive Asturian south of the Plzeň, Radnice and Kladno-Rakovník basins. These rocks are, in general, of late Carboniferous age and overlie Neoproterozoic rocks, mostly separated tectonically from Cambrian or Ordovician units. Only at Merklín is the basement of outliers formed by Neoproterozoic rocks and also by granodiorites of the Stod Massif.

In the Barrandian Basin it is clear that before the deposition of Bolsovian rocks, (after the Asturian in the area of Mirošov) the Lower Paleozoic basin fill sediments must have been folded and strongly deformed before being eroded. We estimate the thickness of rocks eroded from their basement about half that of the thickness of Cambrian to Lower Devonian rocks reported by Chlupáč et al. (2002). This rough estimate is based on assumption that the upper Carboniferous outliers near the city of Plzen are near the SW and NW edges of the Příbram-Jince Basin and similarly also Ordovician rocks in the basement of other upper Carboniferous outliers were deposited close to the Prague Basin margin, where thicknesses were probably reduced. Even at this level of reduction and assuming that the concept of the nappe structure for the Barrandian Lower Paleozoic made by Melichar and Hladil (1999) is not correct, we estimate that as much as $1850 \mathrm{~m}$ of Lower Paleozoic deposits were eroded prior to deposition of the Bolsovian sediments. At Mirošov, Skořice and Kamenný Újezd the thickness of these rocks could have been $3150 \mathrm{~m}$ before the Asturian sedimentation took place. The estimate corresponds more or less to the inferred thickness of Cambrian rocks in the Přibram-Jince Basin given by Fatka and Mergl (2009). However, if we take into consideration the conclusions of studies based on the maturity of organic matter and the analysis of fission products in apatite from the Barrandian Lower Paleozoic that the Middle Devonian rocks were covered by a sequence of pre-upper Carboniferous rocks at least $2-3 \mathrm{~km}$ thick, then a significantly greater thickness of pre-Bolsovian and/or pre-Asturian rocks must have been eroded prior to sedimentation of the Radnice or Nýřany members. 


\section{REFERENCES}

Becq-Giraudon, J.F., Montenat, C., Van den Driessche, J. 1996. Hercynian high-altitude phenomena in the French Massif Central: tectonic implications. Palaeogeogaphy, Palaeoclimatology, Palaeoecology 122, 227-241.

Čepek, L. 1951. Mirošovská kamenouhelná pánev. Sborník Ústředního Ústavu geologického 18, 89-116.

Chlupáč, I., Brzobohatý, R., Kovanda, J., Stráník, Z. 2002. Geologická minulost České Republiky. 436 pp. Academia, Praha.

Fatka, O., Mergl, M. 2009. The microcontinent Perunica: status and story 15 years after conception, 65-101. In Bassett, M.G. (ed.) Early Palaeozoic Peri-Gonwana Terranes: New insights from tectonics and biogeography. Geological Society Special Publication 32, London.

Filip, J., Suchý, V. 2004. Thermal and tectonic history of the Barrandian Lower Paleozoic, Czech Republic: is there a fission-track evidence for Carboniferous-Permian overburden and preWestphalian alpinotype thrusting? Bulletin of Geosciences 79(2), 107-112.

Franců, E., Mann, U., Suchý, V., Volk, H. 1998. Model of burial and thermal history of the Tobolka-1 borehole profile in the Prague basin. Acta Universitatis Carolinae, Geologica 42(3), 248-249.

GEOČR500. 2010. Geological map of the Czech Republic in the scale $1: 500$ 000. Czech Geological Survey, Prague, http://mapy.geology.cz/website/geoinfo/viewer2.htm, 24 May 2010.

GEOČR50. 2010. Geological map of the Czech Republic in the scale 1:50 000. Czech Geological Survey, Prague, http://mapy.geology.cz/website/ geoinfo/viewer2.htm, 24 May 2010.

Geyer, G., Elicki, O., Fatka, O., Żelińska, A. 2008. Cambrian, 155-202. In: McCann, T. (ed.): The geology of Central Europe, Vol. 1. Geological Society of London, London.

Glasmacher, U.A., Mann, U., Wagner, G.A. 2002. Thermotectonic evolution of the Barrandian, Czech Republic, as revealed by apatite fissiontrack analysis. Tectonophysics 359, 381-402.

Gregorová, M. 1961. Petrografické studium ložiska kaolinových hornin v Kaznějově. Sborník Ústředního Ústavu geologického 26(1959), Oddíl geologický, 2, 427-453.

Hajná, J., Žák, J., Kachlík, V., Chadima, M. 2010. Subduction-driven shortening and differential exhumation in a Cadomian accretion wedge: The Teplá-Barrandian unit, Bohemian Massif. Precambrian Research 176, 27-45.

Havlena, V., Pešek, J. 1980. Stratigrafie, paleogeografie a základní strukturní členění limnického permokarbonu Čech a Moravy. Sborník Západočeského muzea., Příroda 34, 1-144.

Havlíček, V. 1951a. Geologická mapa odkrytá, list 4151/2-a/1. MS, unpublished map of the Czech Geological Survey, Praha.

Havlíček, V. 1951b. Geologická mapa odkrytá, list 4151/2-a/3. MS, unpublished map of the Czech Geological Survey, Praha.

Havlíček, V. 1951c. Geologická mapa odkrytá, list 4151/2-a/4. MS, unpublished map of the Czech Geological Survey, Praha.

Havlíček, V. 1971. Stratigraphy of the Cambrian of central Bohemia. Sborník geologických věd, Geologie 20, 7-52.

Havlíček, V. 1980. Vývoj paleozoických pánví v Českém masivu (kambrium-spodní karbon). Sborník geologických věd, Geologie 34, 31-65.

Havlíček, V. 1982. Ordovician in Bohemia: development of the Prague basin and its benthic communities. Sborník geologických věd, Geologie 37, 103-136.

Havlíček, V. 1986. Geologická mapa odkrytá, list 12-34 Horovice. MS, unpublished map of the Czech Geological Survey, Praha.

Havlíček, V., Prantl, F. 1951. Stratigrafický a tektonický výzkum širšího okolí Holoubkova. Vèstník Ústředního Ústavu geologického 26(1), 19-21.

Havlíček, V., Štorch, P. 1986. Geologická mapa odkrytá, list 12-34 Beroun. MS, unpublished map of the Czech Geological Survey, Praha.

Heckel, P.H. 2002. Observations and constraints on radiometric dating Pennsylvanian succession in North America and its correlation with dates from Europe. Newsletter on Carboniferous Stratigraphy 20, 10-14.

Holub, V., Obrhel, J. 1967. Profil karbonskou pánví u Malých Př́lep ssv. od Berouna. Časopis pro mineralogii a geologii, 12(3), 271-276.

Holub, V., Pešek, J., Skoček, V. 1991. The morphology and nature of the basement of the Carboniferous and the source areas in central Bohemia during Late Devonian-Westphalian B time (in Czech). Sborník 6. uhelné konference PřF UK, Praha, 35-43.

Holub, V., Skoček, V., Tásler, R. 1975. Paleogeography of the Late Paleozoic in the Bohemian Mas- 
sif. Paleogeography, Paleoclimatology, Paleoecology 18, 313-332.

Holub, V., Tásler, R., Vozár, J., Vozárová, A., Bajaník, S. 1979. Geologická a paleogeografická mapa karbonu a permu ČSSR. Ústřední ústav geologický, Praha.

Kalibová-Kaiserová, M. 1979. Palynologický výzkum reliktů západně od plzeňské pánve. Věstník Ústředního Ústavu geologického 54(2), 282-290.

Kalibová-Kaiserová, M. 1982. Megaspory a miospory uhelných slojí reliktů karbonu na Plzeňsku. Věstník Ústředního Ústavu geologického 57(1), 95-99.

Klomínský, J., Klener, J., Novák, F., Malec, J., Kvaček, M. 1979. Fosilní zlatonosné rozsypy v karbonu u Křivců (západní Čechy). Časopis pro mineralogii a geologii 24(3), 291-300.

Klomínský, J., Jiránek, J., Malec, J., Novák, F., Odehnal, L., Veselovský, F. 1983. Zlatonosnost kontinentálního permokarbonu Českého masivu. Sborník geologických věd, Ložisková geologie, mineralogie 25, 111-186.

Kodym, O. 1933. Geologické zprávy z širšího okolí Loděnic na listu Kladno (3952). Časopis Národního muzea 107(1-2), 24-27.

Kraft, J. 1962. Geologické poměry širšího okolí Holoubkova. 54 pp. MS, MSc. thesis, Geofond, Praha.

Kraft, J., Kraft, P.: 2006. Geologie Žd’áru, 9-14. In Štastný, V., Hrachová, H., Uherský, M., Kraft, J., Kraft, P., Žán, M. Vrch Žd’ár u Rokycan. V. Št̉astný, Mirošov.

Křriž, J. 1992. Silurian field excursion. Prague Basin (Barrandian), Bohemia. 111 pp. National Museum of Wales, Geological. Series 13, Cardiff.

Kukal, Z. 1984. Granitoidní masivy byly hlavním zdrojem živců permokarbonských sedimentů. Časopis pro mineralogii a geologii 29(2), 193-196.

Martínek, K., Blecha, M., Daněk, V., Franců, J., Hladíková, J., Johnová, R., Uličný, D. 2006. Record of palaeoenvironmental changes in a Lower Permian organic-rich lacustrine succession. Integrated sedimentological and geochemical study of the Rudník member, Krkonoše Piedmont Basin, Czech Republic. Palaeogeography, Palaeoclimatology, Palaeoecology 230, 85-28.

Mašek, J., Straka, J. 1994a. Geologická mapa odkrytá, list 11-33 Plzeñ. MS, unpublished map of the Czech Geological Survey, Praha.
Mašek, J., Straka, J. 1994b. Geologická mapa odkrytá, list 22-11 Přšstice. MS, unpublished map of the Czech Geological Survey, Praha.

Mašek, J., Havlíček, V., Straka, J. 1990. Geologická mapa odkrytá, list 22-12 Březnice. MS, unpublished map of the Czech Geological Survey, Praha.

Mašek, J., Straka, J., Štorch, P. 1983 Geologická mapa odkrytá, list 12-32 Zdice. MS, unpublished map of the Czech Geological Survey, Praha.

Melichar, R., Hladil, J. 1999. Restored and new evidence for early Variscan nappe structures in Central Bohemia. Geolines 8, supplemented poster.

Němejc, F. 1941. Paleontologicko-stratigrafické příspěvky k poznání uhelných revírů severovýchodního okraje plzeňské pánve. Zprávy Geologického Ústavu pro Čechy a Moravu 17, 173-214.

Opluštil, S. 2000. Radnické vrstvy kladenské části kladensko-rakounické pánve. $113 \mathrm{pp}$. MS, $\mathrm{PhD}$ thesis, Charles University in Prague, Czech Republic.

Pertold, Z. et al. 1966. Vysuětlivky ke geologické mapě ČSSR 1:50 000, list M-33-74-D (Stříbro). MS, Geofond, Praha.

Pešek, J. 1960. Příspěvek k poznání produktivního karbonu v okolí Stříbra. Časopis pro mineralogii a geologii 5(1), 71-74.

Pešek, J. 1994. Carboniferous of Central and Western Bohemia. 60 pp. Czech Geological Survey, Prague.

Pešek, J. 2003. Po stopách těžby uhlí v reliktech karbonu v okolí plzeňské a kladensko-rakovnické pánve. Sborník Západočeského muzea., Př́roda $103,1-43$.

Pešek, J., Opluštil, D., Kumpera, O., Holub, V., Skoček, V. (eds) 1998. Paleogeographic atlas. Late Paleozoic and Triassic formations. 53 pp. Czech Geological Survey, Prague.

Röhlich, P. 1965. Geologische Probleme des mittelböhmischen Algonkiums. Geologie 14(4), 373403.

Roscher, M., Schneider, J.W. 2006. Permo-carboniferous climate: Early Pennsylvanian to Late Permian climate development of central Europe in a regional and global context, 95-136. In Lucas, S.G., Cassinis, G., and Schneider, J.W. (eds) Nonmarine Permian chronology and correlation. Geological Society Special Publication 265, London. 
Schneider, J.W., Hoth, K., Gaitzsch, B.G., Berger, H.J., Steinborn, H., Walter, H., Zeidler, M. 2005. Carboniferous stratigraphy and development of the Erzgebirge Basin, East Germany. Zeitschrift Deutsche Gesselschaft and Geowissenschaft 156(3), 431-466.

Sattran, V. 1957. Odnos krystalinika v prostoru východních Krušných hor. Věstník Ústředního ústavu geologického 32(3), 316-322.

Seifert, A., Straka, J., Stárková, M. 1995. Geologická mapa ČR, list 21-22 Holýšov. MS, unpublished map of the Czech Geological Survey, Praha.

Spengler, E. 1939. Über die karbonische Abtragung im Bereich der Böhmischen Masse. Lotos 87(1939/40), 105-136.
Šafanda, J., Suchý, V., Sýkorová, I., Stejskal, M. 2003. Thermal history of sedimentary basins of the Czech Republic and its relation to tectonic progresses. Acta Montana IRSM AS CR, Seria $A B, 11(128), 45-54$.

Vejnar, Z., Pelc, Z., Miksa, V. 1987. Geologická mapa ČSR, list 21-24 Klatovy. MS, unpublished map of the Czech Geological Survey, Praha.

Vejnar, Z., Zoubek, V. 1962. Vysvětlivky $k$ přehledné geologické mapě ČSSR 1 : 200000 M-33-XIX Mariánské Lázně, M-33-XXV Švarcava. 111 pp. Nakladatelství Československé. akademie věd, Praha.

Veleman, J., Cháb, J. 1974. Starší paleozoikum (?) z Hluboké u Žihle. Časopis pro mineralogii a geologii 19(4), 425-428. 